\title{
Sudden Decline of Date Palm Trees Caused by Erwinia chrysanthemi
}

\author{
M. Y. Abdalla, Plant Protection Department, College of Agriculture and Veterinary Medicine, Buraidah, P.O. Box \\ 1482, Saudi Arabia
}

\begin{abstract}
Abdalla, M. Y. 2001. Sudden decline of date palm trees caused by Erwinia chrysanthemi. Plant Dis. $85: 24-26$.

A new bacterial disease of date palm 'sudden decline' was found in the Al-Qassim region, Saudi Arabia. It is characterized by a sudden loss of vigor in the affected trees with the appearance of some blighted inner leaves. Symptoms develop rapidly and the whole tree assumes a straw color in about 2 weeks. The bud union is killed, and massive amounts of slime in a gel-like matrix could be detected in the heart of the affected tree. Biological and physiological tests of the isolated bacterium suggested that it belongs to the species Erwinia chrysanthemi. Artificial inoculation of various date palm cultivars using the technique of infusion under reduced pressure demonstrated that $E$. chrysanthemi was the causal agent and that cv. Succary was the most susceptible cultivar, whereas cvs. Roshody and Helwa were resistant to infection with E. chrysanthemi.
\end{abstract}

Since ancient times, date palm (Phoenix dactylifera L.) trees have been highly valued in the desert regions of Southwest Asia and North Africa. The trees are both drought and salt tolerant, and its tasty fruits have high nutritional value and good storage properties. There are more than 16 million date palm trees in Saudi Arabia (1) and this number is increasing rapidly as more desert areas are being planted with date palms every year.

Starting from the spring of 1995 , date palm growers in the Al-Qassim region (Central Saudi Arabia) have been complaining of a destructive disease that may strike only a few trees in the orchard, especially in young plantations 3 to 7 years old. It usually takes about 2 weeks from the first appearance of a wilted young spear (unopened leaf) until the whole tree is killed. Another week may pass before its suckers also are killed. The disease has been referred to as sudden decline (SD). A bacterial bud rot disease of date palm was described earlier in the Al-Qassim region (2). That disease was found to be an isolated case in an old orchard affecting trees that are more than 50 years old. Serratia marcescence was considered the causal agent of that disease. Bacterial bud rot also has been known to affect oil palm trees (Elaeis guineensis L.) in many parts of the world, including Columbia, Cuba, Ecuador, Nigeria, Republic of Congo, Southeast Asia, the United States (Florida), and Zaire (4). Erwinia spp., including E. carotovora and E. lathyri (syn. E. herbicola), have been suggested as the causal agents in sev-

Accepted for publication 13 September 2000.

Publication no. D-2000-1106-02R

(c) 2001 The American Phytopathological Society eral of these cases. However, the causal role of these bacteria has not been clearly demonstrated (7).

The objectives of this study were to (i) identify the etiological agent involved in the sudden decline of date palm trees, (ii) determine an efficient artificial inoculation technique for date palm seedlings using this pathogen, and (iii) test the response of different date palm cultivars to artificial inoculation with the causal agent.

\section{MATERIALS AND METHODS}

Isolation of the causal agent. Wilted young spears as well as roots of date palm trees which had recently developed the SD symptoms were used for isolation. Plant materials were washed thoroughly under a fine mist of tap water. Leaf rachis tissues were cut into 5-mm cubes and the roots were cut into $1-\mathrm{cm}$ pieces with a sterile scalpel. Tissue pieces were surface sterilized with $0.5 \%$ sodium hypochlorite for 2 $\mathrm{min}$, then rinsed in sterile distilled water (SDW) for another $2 \mathrm{~min}$. Three pieces of either the leaves or the roots tissues were ground in $5 \mathrm{ml}$ of SDW (containing $0.1 \mathrm{M}$ $\mathrm{MgSo}_{4}$ ) using a mortar and pestle. The resulting suspension was streaked onto potato dextrose agar (PDA) medium $(\mathrm{pH}$ 7). Plates were incubated at $28^{\circ} \mathrm{C}$ for $48 \mathrm{~h}$. Discrete colonies were restreaked onto PDA plates twice before being used for biochemical characterization and pathogenicity tests.

Characterization of the pathogen. Seven isolates were used in the identification experiments, four from leaf rachis and three from roots. Isolates were obtained from four fields. Cultures $(48 \mathrm{~h}$ old $)$ on PDA were subjected to various morphological and biochemical tests. Flagella stain was conducted according to Blendon and Goldberg (3). Colony morphology and pigment production was determined on PDA and yeast extract-dextrose calcium carbonate agar (YDCA; 10). Motility was determined using the hanging drop technique. Gram stain, $\mathrm{H}_{2} \mathrm{~S}$ from cysteine, reducing substances from sucrose, gas from glucose, hydrolysis of casein, phenylalanine deaminase, acetoin production, growth at $36^{\circ} \mathrm{C}$, urease production, oxidase, and growth at $5 \% \mathrm{NaCl}$ were evaluated as described by Schaad (13). Indole and phosphatase production were determined as described in Bergey's Manual (10). Gelatin liquefaction was evaluated using the gelatin plate method as described by Cowan (5). Potato rot, nitrate reduction, and pectate degradation tests were performed according to Lelliot et al. (11). Deoxyribonuclease activity was tested after 2 days on DNase test agar (Difco Laboratories, Detroit). Urease production was detected by change in color of Difco's urea broth as described by Dickey (6). Sensitivity of the isolated bacterium to erythromycin was determined on MuellerHinton agar using Difco's antibiotic discs containing erythromycin $(15 \mu \mathrm{g})$. Production of acid from carbohydrates was tested in $1 \%(\mathrm{wt} / \mathrm{wt})$ organic compound as described by Dye (8).

Pathogenicity tests. Six-month-old date palm seedlings grown from seeds of the local cultivar Succary were used in the pathogenicity tests. Ten seedlings (one/pot) were used in each treatment. Bacterial suspension from 48-h-old cultures on PDA were collected in SDW and adjusted to $1 \times$ $10^{7} \mathrm{CFU} / \mathrm{ml}$ turbidimitrically. In the first experiment, three inoculation procedures were used: (i) spraying the bacterial suspension on the leaves of the date seedlings to the point of run-off, (ii) injecting $2 \mathrm{ml}$ of the bacterial suspension into the crown area of the date palm seedlings, using a 5$\mathrm{ml}$ syringe, and (iii) infusion under reduced pressure, a method originally suggested by Mepsted et al. (12) for selection of resistance to Fusarium wilt in oil palm. With the infusion method, seedlings were removed carefully from the pots and washed thoroughly under a fine mist of tap water to remove soil particles. Each seedling was infused with $1 \mathrm{ml}$ of the bacterial suspension under reduced pressure $(1,500 \mathrm{~Pa})$ as suggested by Mepsted et al. (12). Seedlings were then replanted in their pots. Control plants were either sprayed, injected, or infused with SDW. All pots were watered and covered separately with plastic bags for $48 \mathrm{~h}$. Plastic bags were removed and pots were randomly arranged on the green- 
house bench at 20 to $30^{\circ} \mathrm{C}$ and 60 to $90 \%$ relative humidity. All experiments were repeated three times. A disease rating scale similar to that suggested by Haygood and Strider (9) was applied, where $-=$ leaf chlorosis absent, $+=$ less than half of the leaf became chlorotic, $++=$ more than half of the leaf became chlorotic, and $+++=$ whole leaf chlorosis (blight).

Reaction of date palm cultivars to infection with $\boldsymbol{E}$. chrysanthemi. The local date palm cultivars used in this study were Helwa, Maktoomy, Nabt Aly, Roshody, and Succary. Four seeds were planted into each seedling bag (pot) filled with autoclaved (1:1 vol/vol) sandy loam soil and peat moss, and five bags were used for each cultivar. The bags were placed in the greenhouse at 20 to $30^{\circ} \mathrm{C}$. Six months after cotyledon appearance, seedlings were carefully removed to minimize root damage. Plants were then inoculated with the above-mentioned bacterial suspension through the cotyledon using the infusion method described. Control seedlings were infused similarly with SDW. Seedlings were replanted in their pots. All pots were treated as mentioned above in the pathogenicity tests. This experiment was repeated twice. Disease ratings were determined 1 week after inoculations as follows: $0=$ no visible symptoms, $1=5$ to $10 \mathrm{~mm}$ of the cotyledon tip became chlorotic, $2=1$ to $3 \mathrm{~cm}$ of the cotyledon tip became chlorotic, $3=3$ to $7 \mathrm{~cm}$ of the cotyledon (starting from the tip) became chlorotic, and $4=$ whole cotyledon chlorotic. The experiment was arranged as a randomized block design. Data were analyzed according to general linear models procedures of the SAS program (Statistical Analysis System, version 6.12; SAS Institute, Inc., Cary, NC).

\section{RESULTS}

Disease symptoms. Infected palm trees suddenly show the symptoms of vigor loss. This is manifested in pale-green discoloration of inner leaves. This discoloration starts from the top of the leaf and moves downward. Symptoms advance to the outer leaves, which assume a grayish-green color that turns tan with blight progression. The innermost leaves may become yellowish and lean to one side. The bases of these inner leaves then exhibit a brown discoloration, rot, and the leaves can be pulled out easily. The disease will eventually reach the bud union and the tree is killed. A gel-like matrix composed of masses of the bacteria with a foul smell can be detected in the heart of these trees. A crosssection of a leaf rachis from infected trees often reveals a light brown discoloration of the vascular tissues. Roots of infected trees will also have brown discoloration of the vascular tissues.

Isolation and identification of the causal agent. Creamy white colonies on PDA were consistently isolated from both leaf rachis and roots of diseased trees. The purified cultures of this bacterium incubated on PDA for 4 days gave umbonate colonies with undulate margins (fried-egg shape). The bacterium was rod shaped, gram negative, motile with peritrichous flagella, and could grow anaerobically. The bacterium grew at $36^{\circ} \mathrm{C}$ but did not grow in $5 \% \mathrm{NaCl}$. The bacterium was negative for urease activity, gluconate oxidation, phenylalanine deaminase, and deoxyribonuclease. Acid was not produced from lactose, maltose, and trehalose. Findings were positive for indole production, $\mathrm{H}_{2} \mathrm{~S}$ from cysteine, acetoin, pectate degradation, production of gas from D-glucose, gelatin liquefaction, nitrate production, and phosphatase. The bacterium was sensitive to erythromycin (15 $\mu \mathrm{g} /$ disc $)$.

Based on these tests, the bacterial isolates obtained from date palm were identified as $E$. chrysanthemi as described in Bergey's Manual (10).

Pathogenicity tests. Results of the inoculation methods experiment (Table 1) indicated that spraying the cell suspension $\left(1 \times 10^{7} \mathrm{CFU} / \mathrm{ml}\right)$ of $E$. chrysanthemi on date palm seedlings did not produce any disease symptoms during the course of the experiment. Injection of $E$. chrysanthemi inoculum resulted in the appearance of disease symptoms 1 week after inoculation. Disease development using the injection technique was slow when compared to the infiltration method (Table 1). Leaf chlorosis of date palm seedlings appeared within 3 days after inoculation with the infiltration under reduced pressure method. These results were consistent in all three trials of the experiment.

Cultivar resistance to E. chrysanthemi. Based on the results obtained from the inoculation methods experiments, distinguishing between resistant and susceptible date palm cultivars was attempted by using the efficient inoculation technique of infusion under reduced pressure. Various date

Table 1. Response of date palm seedlings (cv. Succary) to different inoculation methods with Erwinia chrysanthemi

\begin{tabular}{llll}
\hline & \multicolumn{3}{c}{ Days after inoculation } \\
\cline { 2 - 4 } Method $^{\mathrm{w}}$ & $\mathbf{3}$ & $\mathbf{7}$ & $\mathbf{1 4}$ \\
\hline Spraying $^{\mathrm{x}}$ & - & - & - \\
Injection $^{\mathrm{y}}$ & - & + & ++ \\
Infiltration $^{\mathrm{z}}$ & + & +++ & +++ \\
\hline
\end{tabular}

${ }^{\mathrm{v}}$ Disease rating on date palm seedlings: $-=$ no leaf chlorosis, $+=$ less than half of the leaf became chlorotic, $++=$ more than half of the leaf became chlorotic, and $+++=$ whole leaf chlorosis(blight).

${ }^{\mathrm{w}}$ All inoculation methods were performed using an inoculum concentration of $1 \times 10^{7}$ $\mathrm{CFU} / \mathrm{ml}$ of $E$. chrysanthemi.

${ }^{x}$ Seedlings were sprayed with bacterial suspension until run-off.

y Seedlings were injected in the crown area with $2 \mathrm{ml}$ of bacterial suspension.

${ }^{\mathrm{z}}$ Seedlings were infused with $1 \mathrm{ml}$ of bacterial suspension under reduced pressure. palm cultivars reacted differently to infection with E. chrysanthemi. The degree of infection for the various cultivars was rather consistent over the three performed trials (Table 2). Cv. Succary was the most susceptible, whereas Roshody and Helwa were resistant to infection with $E$. chrysanthemi.

\section{DISCUSSION}

The bacterial isolate obtained from date palm in this study is morphologically and biochemically identical to E. chrysanthemi as described in Bergey's Manual (10). A representative strain of this bacterium was sent to the International Mycological Institute (IMI, now known as CABI Bioscience, UK), where a lipid analysis was performed for this isolate. The bacterium was identified again as E. chrysanthemi and designated as IMI 378427. This bacterium can cause a complete blight for the artificially inoculated date palm seedlings in about 1 week. Therefore, it was concluded that the causal agent of the sudden decline of date palm described in this article is E. chrysanthemi.

Similar symptoms of SD of date palm, which include rot of inner leaves and buds with the presence of structureless and evilsmelling mass near the center of the crown, have been previously described on oil palm. This pathological condition of oil palm has been shown to be due to an $E r$ winia sp. similar to E. lathyri (7). The disease has occurred sporadically in most countries where it is found. In South Congo, however, it has caused the death of a large number of oil palms (7).

The inoculation experiments performed in this study and the failure of the inoculum spray method to cause any disease symptoms may suggest insect transmission of the pathogen into date palm tissues. Further work is needed to determine if any of the insects found associated with this malady, such as the Nitidulid beetles, are responsible for the introduction or spread of $E$. chrysanthemi in date palm.

The inoculation technique of infusion under reduced pressure was developed by

Table 2. Disease ratings on 6-month-old seedlings of different date palm cultivars inoculated with Erwinia chrysanthemi

\begin{tabular}{lccc}
\hline & \multicolumn{3}{c}{ Disease severity index } \\
\cline { 2 - 4 } Cultivar & Trial 1 & Trial 2 & Trial 3 \\
\hline Helwa & $2.1 \mathrm{bc}$ & $1.9 \mathrm{~b}$ & $2.1 \mathrm{c}$ \\
Maktoomy & $2.8 \mathrm{ab}$ & $3.1 \mathrm{a}$ & $3.4 \mathrm{ab}$ \\
Nabt-Aly & $3.1 \mathrm{a}$ & $3.2 \mathrm{a}$ & $2.9 \mathrm{~b}$ \\
Roshody & $1.8 \mathrm{c}$ & $1.9 \mathrm{~b}$ & $2.1 \mathrm{c}$ \\
Succary & $3.5 \mathrm{a}$ & $3.4 \mathrm{a}$ & $3.7 \mathrm{a}$ \\
\hline
\end{tabular}

${ }^{\mathrm{z}}$ Disease ratings on date palm seedlings: $0=$ no visible symptoms, $1=$ small lesion $(5$ to 10 $\mathrm{mm}$ in length), 2 = medium-size lesion ( 1 to 3 $\mathrm{cm}$ in length), $3=$ large lesion ( 3 to $7 \mathrm{~cm}$ in length), $4=$ whole-leaf blight. Values in a column followed by the same letter are not significantly different according to Duncan's multiple range test $(P=0.05)$. 
Mepsted et al. (12) as a model system for rapid detection (8 days) of Fusarium wiltresistant lines of oil palm. They also found that the results obtained by this method were more consistent compared with conventional resistance screening trials, in which the degree of infection frequently varied between trials. Similarly, the work presented in this study (Table 2) revealed that, using this technique, the reaction of date palm cultivars to infection with $E$. chrysanthemi was consistent over the three performed trials. The tested date palm cultivars exhibited various levels of susceptibility to E. chrysanthemi. Succary, the most popular and expanding cultivar in the region, proved to be the most susceptible among all tested cultivars. This may increase the risk of an epidemic if all environmental conditions are optimal for the development of this disease. The fact that cvs. Roshody and Helwa demonstrated significant resistance to this newly described disease compared with the other tested cultivars may be helpful in understanding disease pathogenesis and in developing breeding program for its control.

\section{LITERATURE CITED}

1. Agricultural Statistical Year Book. 1998. Agriculture and Water Ministry of Saudi Arabia. Riyadh.

2. Al-Rokibah, A. A. 1996. Apical bud rot of date palm in Al-Qassim, Saudi Arabia. Bull. Fac. Agric. Univ. Cairo 47:639-648.

3. Blendon, D. C., and Goldberg, H. S. 1965. Silver impregnation stain for Leotospira and flagella. J. Bacteriol. 89:899-900.

4. Chase, A. R., and Broschat, T. K. 1991. Bacterial bud rot. Pages 3-4 in: Diseases and Disorders of Ornamental Palms. American Phytopathological Society, St. Paul, MN.

5. Cowan, S. T. 1974. Cowan and Steel's Manual for the Identification of Medical Bacteria. 2nd ed. Cambridge University Press. London.

6. Dickey, R. S. 1979. Erwinia chrysanthemi : A comparative study of phenotypic properties of strains from several hosts and other Erwinia species. Phytopathology 69:324-329.

7. Duff, A. D. S. 1962. Bud rot disease of the oil palm. Nature 195:918-919.

8. Dye, D. W. 1968. A taxonomic study of the genus Erwinia. I. The "amylovora" group. N. Z. J. Sci. 11:590-607.

9. Haygood, R. A., and Strider, D. L. 1982. A comparison of inoculation methods of $\mathrm{Er}$ winia chrysanthemi in greenhouse ornamentals. Plant Dis. 66:461-463.

10. Krieg, N. R., and Holt, J. G., eds. 1984. Bergey's Manual of Systematic Bacteriology. Vol. 1. Williams and Wilkins, Baltimore.

11. Lelliott, R. A., and Stead, D. E. 1987. Methods for the Diagnosis of Bacterial Diseases of Plants. Blackwell Scientific Publication, Oxford.

12. Mepsted, R., Flood, J., Paul, T., Airede, C., and Cooper, R. M. 1995. A model system for rapid selection for resistance and investigation of resistance mechanisms in Fusarium wilt of oil palm. Plant Pathol. 44:749-755.

13. Schaad, N. W., ed. 1980. Gram-negative bacteria, B. Erwinia. Pages 26-34 in: Laboratory Guide for Identification of Plant Pathogenic Bacteria. American Phytopathological Society, St. Paul, MN. 